Macroeconomic Variables and Stock Market Performance in Sri Lanka: An ARDL Bound Testing Approach
South Asian Journal of Business Insights 2021,1(2), 43-58. ISSN 2773-7012(print) ISSN 2773-6997(online) (C) 2021, Faculty of Management and Finance University of Ruhuna, Sri Lanka

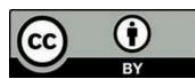

\title{
Lingesiya Kengatharan*
}

Department of Financial Management, University of Jaffna, Sri Lanka

\section{Jeyan Suganya Dimon Ford}

Department of Financial Management, University of Jaffna, Sri Lanka jeyansuganya@univ.jfn.ac.lk

\begin{abstract}
The aim of the study is to examine the impact of macroeconomic variables on stock market performance in Sri Lanka. This study uses yearly data collected from the annual reports of the Central Bank of Sri Lanka for the period from 1990 to 2019. Macroeconomic variables used in this study are interest rate, inflation rate, real exchange rate, and money supply while All Share Price Index (ASPI) is used to measure the stock market performance. Inflation rate and interest rate are found stationary at zero levels while exchange rate, money supply and stock market performance are found stationary at levels one in the Augmented Dickey-Fuller (ADF) test. No serial correlation is found among variables by employing Breusch-Godfrey LM Test. The Auto-Regressive Distributed Lag (ARDL) bounds test is used to test the long-run and short-run relationships between variables. The empirical result reveals that there is a negative and significant impact of interest rate and inflation rate on stock market performance while exchange rate and money supply do not hold any significant impact on stock market performance in the long run. Further, it is found that there is a negative and significant impact of interest rate on stock market performance in the short run.
\end{abstract}

Keywords: ARDL Bound Test, ASPI, Macroeconomic Variables, Stock Market Performance

\footnotetext{
* Corresponding Author- lingesiya@univ.jfn.ac.lk
} 


\section{Introduction}

The stock market is one of the elements of the financial market. It is the place where ownership of investible assets can be bought and sold by investors. An efficient stock market is considered vital to economic development since it allows companies to quickly access capital from the public by increasing liquidity in the market. A stock market in a country is functioning for mobilizing national and international capital between various parties. It leads to the growth of industries and commerce in a particular country. The health of a stock market is one of the major indicators of the economic position of such a country because, if an economy is growing, the output will also be increasing, and most firms should be experiencing increased profitability. It will make the company shares more attractive and they can give higher dividends to shareholders. A long period of economic growth will tend to benefit shares.

There is only one share market in Sri Lanka named Colombo Stock Exchange (CSE), which provides a platform to investors for buying and selling shares. The performance of all companies listed on the CSE in Sri Lanka is measured with the Colombo ASPI, which is considered a major stock market index and a capitalization-weighted index. The Colombo All-Share Index has a base value of 100 in 1985. The performance stock market was declined in the first quarter of 2020 due to the announcement of a pandemic declared by the World Health Organisation (WHO). However, the world beating performance of the ASPI has been identified as consistent with noteworthy levels of trading activity recorded in the Sri Lankan stock market in 2021.

There are many factors influencing stock market performance in a country such as company internal factors (management quality, divided policy, nature, size, financial position, etc) and external factors (political, economic, technological, geographical, demographical, etc). Most of the prior studies (Allahawiah and Al-Amro, 2012; Thuy, 2018; Utami et al., 2015) found that macroeconomic variables had a higher impact on stock market performance than other factors. Therefore, several studies done in various countries analyzed the relationship between macroeconomic variables and stock market performance (Emenyi and Effiong, 2020; Sahoo et al., 2020; Kalam, 2020; Utomo et al., 2019; Khan and Khan, 2018; Chandrashekar et al., 2018; Ullah et al., 2017; Robert, 2016, Laichena and Obwogi, 2015; Mohapatra and Rath, 2015; Hunjra et al., 2014). In addition, plenty of research has been done in Sri Lanka to examine the impact of macroeconomic variables on stock market performance (Badullahewage, 2015; Hemamala and Jameel, 2016; Lakmali and Madhusanka, 2015; Menike, 2006; Morawakage, 2013; Nanayakkara and Darshi, 2015; Nijam et al., 2015; Perera, 2015; Rathnayaka and Seneviratna, 2017; Shafana, 2014; Wickremasinghe, 2011). However, the results from each study were not a consensus as the period of study, statistical techniques used for analysis, variables were chosen for study were different from one another. There is a need for conducting research from time to time for measuring how the volatility of macroeconomic variables influences the performance 
of the stock market in a country. Therefore, it was decided to execute the study with the major aim of examining the impact of macroeconomic variables on stock market performance in Sri Lanka. In order to test the hypotheses of the study, time series analysis is employed as it is a study with time-series data. Investors and policymakers are considered as major parties to whom findings of this study will give capable knowledge to predict stock market performance with the changes of macroeconomic factors and to forecast and develop regulations and policies respectively.

In the subsequent section, the theoretical and empirical literature is reviewed, followed by methodology consisting of model specification and data collection. Consequently, the results are revealed together with discussions. Finally, it is concluded with implications and future recommendations.

\section{Literature Review}

There are a few theories, which support predicting the relationship between macroeconomic variables and stock market performance. Arbitrage pricing theory (Ross, 1976) says that stocks can be valued by creating a relationship between monetary policy variables and stock market return. Further, it says that the stock price can be changed with the investment decision made by investors which are affected by fundamental macroeconomic variables. Individual security return (CAPM) and its extension aggregate stock market framework are used in this theory for determining stock return (Ross, 1976).

Random walk theory (Burton, 1973) reveals that the availability of new information can influence the security holding behaviour of investors. Therefore, it follows efficient capital market hypotheses, which argue that stock prices are random and no one can be benefited from profitable speculation in the stock market. Random stocks are unexpected or unpredictable events that can affect the stock market either positively or negatively (Moore, 1962; Fama, 1965). The efficient market theory (Fama, 1970) explains that all the investors are aware of relevant new information about the changes in macroeconomic factors, which affect the current stock prices and hence, there is no opportunity for investors to earn irregular profits in such markets (Fama, 1970).

In order to analyze existing theories that prove a strong relationship between macroeconomic variables and stock market performance, considerable research was carried out by several researchers in various countries. Bhuiyan and Chowdhury (2020) intended to analyze how certain macroeconomic variables influence different sectors of the stock market differently in the US and Canada. Cointegration and Vector Error Correction Models were employed using monthly data over the 2000-2018 period. They found that there was a negative influence of money supply on stock indices while 
the interest rate influences negatively in the US. However, they could not find any clear link between macroeconomic variables and stock market indices in Canada.

Olomu (2015) examined the impact of macroeconomic variables on the UK stock market using monthly time series data from January 1995 to December 2014. The long-run and short-run equilibrium relationships were determined by the Vector Error Correction model. It was found that the consumer price index and exchange rate revealed a positive relationship with the FTSE100 Index over the long run, whereas the industrial production index, money supply and interest rate showed negative long-run relationships with the FTSE100 Index. The Vector Error Correction Model in the short run suggested that exchange rate and industrial production index restore equilibrium as they both deviate in the short run but adjust to equilibrium in the long run. Bi-directional causality between the consumer price index and industrial production index and unidirectional causality between FTSE 100 and exchange rate, FTSE 100 and industrial production index, money supply, and interest rate, interest rate and industrial production index, exchange rate and money supply, money supply and industrial production index, exchange rate and industrial production index were found in Granger causality test. Demir (2018) conducted a study to analyze the impacts of some prominent macroeconomic factors on the Turkish Stock Market index, BIST-100. The findings generated from the quarterly data by employing the ARDL Bounds Test revealed that economic growth, the relative value of the domestic currency, portfolio investments and foreign direct investments raise the stock market index while interest rate and crude oil prices negatively affect it.

Kalam (2020) found a positive and significant impact of inflation on the stock market in Malaysia. The researcher argued that the reason behind the positive effect is the support of the government on the industry development and pushing the poverty towards the wall by creating new employment. The interest rate had a negative and significant impact on the stock market while gross domestic product negatively and significantly influenced it. Chen et al., (2019) investigated the influences of macroeconomic variables on the stock market in China by using Granger causality tests, impulse response functions, and variance decompositions. The results of the study revealed that output growth and inflation had no statistically significant impact on stock returns. Moreover, the stock returns did not respond to changes in monetary policy variables such as money supply and short-term interbank offered rate. This implies that monetary policy does not exert significant influences on stock returns. They concluded their study by stating that the performance of the China stock market did not reflect macroeconomic fundamentals.

Moreover, numerous studies were done in Sri Lanka to find the impact of macroeconomic variables on stock market performance by many scholars in various periods. Rathnayaka and Seneviratna (2017) examined the relationship between stock market indices and macroeconomic factors in Sri Lanka during the period from January 2009 to December 2016 using monthly data. It was found that there were no unit root issues in all variables in their first differences by employing the ADF test statistic and Phillips-Perron test statistic 
(PP). The estimated co-integration rank test and Max-Eigen value test revealed that there were two co-integration equations. Furthermore, the study concluded that CSE is highly sensitive to the real gross domestic product and broad money supply.

Nanayakkara and Darshi (2015) carried out a study to investigate the impact of macroeconomic variables on ASPI using extracted data for the period from 2004 to 2014 . They found that interest rate, exchange rate, inflation rate and the fiscal deficit had a negative impact while GDP and treasury bill interest rate had a positive impact on ASPI. It further revealed that GDP was the most significant variable in affecting stock market performance in Sri Lanka. In this research, the stationary status of the variables was not tested and time series analysis was not employed. Jayasundara et al. (2019) found that there was a negative relationship between interest rate and ASPI and exchange rate and real GDP growth had a positive relationship with ASPI in Sri Lanka using data for the period from 2006 to 2016 . It was revealed by the ordinary least square method. Badullahewage (2015) analyzed the impact of macroeconomic factors on the stock market performance in Sri Lanka employing regression analysis with data from 1999 to 2005. Results of the study revealed that an upward movement in the factors like interest rate, exchange rate, and GDP lead to a better performance of ASPI. However, the inflation rate should be as much minimum as possible to have a better performance in the stock market. Jahfer and Irfan (2014) investigated the contribution of macroeconomic variables in stock market performance. All variables were found as stationary at first differences in the ADF test. The Johansen test proved that there is a long-run equilibrium relationship between the variables and there is at least one cointegration equitation for ASPI. Further found that the results of Vector Error Correction (VEC) model said short-run relationship of ASPI was found with money market rate and money supply. Nijam et al., (2015), intended to investigate the relationships between the All Share Price Index of the Colombo stock exchange with the data collected from 1980 to 2012. Ordinary Least Square (OLS) was used to estimate the parameters of the regression model, by applying linear, linear-log, log-log, and log-linear data transformation for choosing the appropriate model fitting the data. No serial correlation issue was found in Durbin-Watson statistics. It was observed that the stock market index significantly and positively relates to GDP, exchange rate and interest rate while it is negatively related to inflation proxied by the wholesale price index of Sri Lanka. Morawakage (2013) found the same relationship between exchange rate and ASPI in Sri Lanka for 11 years beginning from 2000. In contrast, Menike (2006) and Joseph (2013) revealed a negative relationship between exchange rate and stock market performance in Sri Lanka. Nevertheless, no significant relationship was found between exchange rate and ASPI in the studies done by Perera (2015) and Wickramasinghe (2011) in Sri Lanka. 
Furthermore, Menike (2006) and Hemamala (2016) found a negative relationship between inflation and stock market performance in Sri Lanka while Safana (2012) revealed a positive relationship of inflation with ASPI. However, Nijam et al., (2015), Perera (2015), Wickramasinghe (2011) and Lakmali and Madhusanka (2015) argued that there was no relationship between inflation and stock market performance in Sri Lanka. Menike (2006) and Perera (2015) argued that there was a positive relationship between money supply and stock market performance. Menike (2006) and Amarasinghe (2015) stated that there was a negative relationship between interest rate and ASPI in Sri Lanka.

According to the literature reviewed, even though many scholars tried to investigate the behaviour of stock market performance measured with ASPI with the changes of macroeconomic variables, there is a need to continue similar research from time to time since different results were revealed in various periods. Therefore, this study aims to fill the gap which was found in the prior studies. Most of the studies carried out in Sri Lanka (Menike, 2006; Perera, 2015; Lakmali and Madhusanka, 2015) used multiple regression analysis to test the hypothesis rather than using time series analysis without considering stationary among variables used in particular studies. Jayasundara et al. (2019) found mixed levels stationary of variables at levels zero and one. However, they have employed only Ordinary Least Square analysis for presenting their result instead of using the ARDL bounds test. Further, investors in the stock market should make an investment decision based on the current scenario. Therefore, it is needed to motivate them with the present trend of macroeconomic variables and its relationship with stock market performance in Sri Lanka with the relevant statistical analysis.

\section{Methods}

\section{Data Collection}

The current study focuses primarily on time series data. The annual reports of the Central Bank of Sri Lanka from 1990 to 2019 were the primary data sources for this analysis. For each of the variables, the study used 30 annual observations. Variables and their measurements are given in Table 1.

The dependent variable in this analysis was stock market performance, which was determined by the ASPI, while the independent variables were real exchange rate, interest rate, inflation, and money supply. Thus, this study intends to investigate the impact of selected macroeconomic variables on stock market performance in Sri Lanka. 
Lingesiya Kengatharan and Jeyan Suganya Dimon Ford

Table 1: Variables and Measurements

\begin{tabular}{ll}
\hline \multicolumn{1}{c}{ Variables } & \multicolumn{1}{c}{ Measurements } \\
Stock Market Performance (LSMP) & $\begin{array}{l}\text { Log of All Share Price Index } \\
\text { Log of the real exchange rate (rupees against } \\
\text { Real Exchange Rate (LEXC) }\end{array}$ \\
$\begin{array}{l}\text { the dollar) } \\
\text { Log of Average weighted prime lending rate/ } \\
\text { Interest Rate (LINT) }\end{array}$ & $\begin{array}{l}\text { Log of Consumer's price index } \\
\text { Inflation (LINF) }\end{array}$ \\
Money Supply (LMS) & Log of Money Supply in real terms \\
\hline
\end{tabular}

\section{Model Specification}

The long-run relationship is estimated using the following ARDL model specified as:

$$
\begin{aligned}
\operatorname{Ln} \cdot Y t=\varphi 0+ & \beta 1 \cdot \operatorname{Ln} Y \cdot t-1+\beta 2 \cdot \operatorname{Ln} X 1 \cdot t-1+\beta 3 \cdot \operatorname{Ln} X 2 \cdot t-1+\beta 4 \cdot \operatorname{Ln} X 3 \cdot t-1 \\
& +\beta 5 \cdot \operatorname{Ln} X 4 \cdot t-1 \\
& +\mu t
\end{aligned}
$$

The short-run dynamic relationship is estimated using error correction model (ECM) specified as:

$$
\begin{aligned}
\Delta \cdot \operatorname{Ln} Y \cdot t=\varphi 0 & +\sum_{n=1}^{p} \varphi 1 \cdot \Delta \cdot \operatorname{Ln} Y \cdot t-i+\sum_{n=0}^{p} \varphi 2 \cdot \Delta \cdot \operatorname{LnX} 1 \cdot t-i \\
& +\sum_{n=0}^{p} \varphi 3 \cdot \Delta \cdot \operatorname{LnX} 2 \cdot t-i+\sum_{n=0}^{p} \varphi 4 \cdot \Delta \cdot \operatorname{LnX} 3 \cdot t-i \\
& +\sum_{n=0}^{p} \varphi 5 \cdot \Delta \cdot \operatorname{LnX} 4 \cdot t-i+\delta e c m \cdot t-1+\mu t
\end{aligned}
$$

Where, $Y$ : refers to Stock market performance; $X 1$ : refers to Real exchange rate; $X 2$ : refers to the interest rate; $X 3$ : refers to inflation; $X 4$ : refers to Money supply; $\mu$ t: white noise; $\phi 0$ : the constant term; $\beta 1-\beta 5$ : long-run elasticity (coefficients of the explanatory variables); $\phi 1-$ $\phi 5$ : short-run elasticity (coefficients of the first-differenced explanatory variables);ecm $t$ - 1 : error correction term lagged for one period; $\Delta$ : first difference operator; $\delta$ : speed of adjustment; p: lag length; Ln: natural logarithm.

ADF test was employed to examine the stationary status of the data. According to the unit root results presented in Table 2, interest rate and inflation were considered as stationary at zero levels since the $P$-value of these two variables were less than 0.05 . On the other hand, as per the results of the unit root, stock market performance, exchange rate and money supply were not stationary at zero levels. 
South Asian Journal of Business Insights

\begin{tabular}{|c|c|c|c|c|c|}
\hline \multicolumn{6}{|c|}{ Table 2: Unit Root Analysis of Variables } \\
\hline \multirow{2}{*}{ Variables } & Zero Level & & $1^{\text {st }}$ Level & & Conclusion \\
\hline & t statistics & Prob. & t statistics & Prob. & \\
\hline Stock Market & -2.0141 & 0.5695 & -4.1598 & 0.0149 & $\mathrm{l}(1)$ \\
\hline \multicolumn{6}{|l|}{ Performance (LSMP) } \\
\hline Exchange Rate (LEXC) & -1.4286 & 0.8305 & -4.7157 & 0.0040 & $\mathrm{I}(1)$ \\
\hline Interest Rate (LINT) & -4.5193 & 0.0064 & & & $\mathrm{I}(0)$ \\
\hline Inflation Rate (LINF) & -4.6438 & 0.0046 & & & $\mathrm{I}(0)$ \\
\hline Broad Money Supply & & & & & $\mathrm{l}(1)$ \\
\hline (LMS) & -0.9186 & 0.9396 & -7.2938 & 0.0000 & \\
\hline
\end{tabular}

Source: Survey Data, 2021.

Thus, it was conducted by considering the first level difference and then it was considered as stationary as they have consisted with $5 \%$ level of significance at level one.

\section{Selection of Lags}

Following the verification of the stationary status of the data, the analysis used VAR lag order selection to determine the optimal lag duration. According to the results illustrated in table 3, the optimum lag period in this analysis was determined to be three lags based on $\mathrm{AIC}, \mathrm{SC}$ and $\mathrm{HQ}$.

Table 3: VAR Lag Order Selection Criteria

\begin{tabular}{|c|c|c|c|c|c|c|}
\hline Lag & LogL & LR & FPE & AIC & $\mathrm{SC}$ & $\mathrm{HQ}$ \\
\hline$\overline{0}$ & 88.60724 & $\mathrm{NA}$ & $1.41 \mathrm{e}-09$ & -6.193129 & -5.953159 & -6.121773 \\
\hline 1 & 199.0483 & 171.7972 & $2.60 \mathrm{e}-12$ & -12.52210 & -11.08228 & -12.09396 \\
\hline 2 & 233.1061 & 40.36478 & $1.65 e-12$ & -13.19304 & -10.55338 & -12.40813 \\
\hline 3 & 285.7185 & $42.86936 *$ & $4.04 \mathrm{e}-13^{*}$ & $-15.23841^{*}$ & $-11.39889^{*}$ & -14.09672 \\
\hline
\end{tabular}

* Indicates lag order selected by the criterion

Endogenous variables: LASPI, LEXC, LINF, LINT, LMS

LR: Sequential modified LR test statistic (each test at $5 \%$ level) ; FPE: Final prediction error; AIC: Akaike information criterion; SC: Schwarz information criterion; HQ: Hannan-Quinn information criterion

Null hypothesis: No serial correlation at up to 3 lags 


\section{Diagnostic Tests}

The Breusch-Godfrey Serial Correlation LM Test was used to check for the existence of serial correlation, which was not found in the model. Table 4 summarizes the findings.

Table 4: Breusch-Godfrey Serial Correlation LM Test:

\begin{tabular}{llcl}
\hline F-statistic & 0.647716 & Prob. $F(3,10)$ & 0.6020 \\
Obs*R-squared & 4.392895 & Prob. Chi-Square(3) & 0.2220
\end{tabular}

No serial correlation at $5 \%$ level

\section{ADRL Bounds Test}

The ARDL Bounds Test was used to test long-run relationship in model 1, since three variables had stationary status at zero levels and two variables had stationary at level one. The finding in Table 5 shows that the variables have a long-term relationship since the Fstatistic value is greater than the upper bound at all levels of significance.

Table 5: Bounds F-test for long run relationships

\begin{tabular}{lcc}
\hline \multicolumn{1}{c}{ Lag } & \multicolumn{2}{c}{$F=6.0708^{* *}$} \\
Significance & $\mathrm{l}(\mathrm{O})$ Bound & $\mathrm{I}(1)$ Bound \\
\hline $10 \%$ & 2.45 & 3.52 \\
$5 \%$ & 2.86 & 4.01 \\
$2.5 \%$ & 3.25 & 4.49 \\
$1 \%$ & 3.74 & 5.06 \\
\hline
\end{tabular}

The null hypothesis states that no long-run relationship exists, while the alternative hypothesis states that a co-integrating relationship exists. It is worth noting that the $\mathrm{F}$ statistic is 6.0708 , which is higher than any of the upper bounds at the $1 \%, 2.5 \%, 5 \%$, and $10 \%$ significance stages. As a result, the null hypothesis was rejected and the alternative hypothesis was accepted. As a result, it was determined that there is a longrun relationship between independent variables and the dependent variable in this study.

\section{Autoregressive Distributed Lag Model}

The ARDL test was used because three variables showed stationary at zero level and the other two variables showed stationary at the first difference (Nkoro and Uko, 2016). Table 6 displays the results of the ARDL test.

The long-run relationship between macroeconomic variables and stock market performance was examined using the ARDL test and the results of the ARDL test was presented in table 6 . As per the results presented in Table 7, the model was significant (F 
South Asian Journal of Business Insights

$=66.9144, p=0.000$ ). Among the macroeconomic variables considered in this study, the exchange rate $(p>0.05)$ and money supply $(p>0.05)$ have not shown any significant impact on stock market performance, which is consistent with the results of the studies done by Perera (2015) and Wickramasinghe (2011) regarding exchange rate and Joseph (2013) regarding money supply and ASPI. Inflation $(p<0.05)$ and interest rate $(p<0.05)$ have shown a significant negative impact on stock market performance, which is consistent with findings revealed by Menike (2006), Joseph (2013) and Hemamala (2016) regarding inflation and ASPI. Moreover, it is congruent with Menike (2006) and Amarasinghe (2015) regarding the interest rate and ASPI.

Table 6: Autoregressive Distributed Lag Estimates. ARDL (3, 3, 0, 3, 0) selected

\begin{tabular}{lcccc}
\hline \multicolumn{1}{c}{ Variable } & Coefficient & Std. Error & t-Statistic & Prob. $^{*}$ \\
\hline LASPI(-1) & 0.993371 & 0.190473 & 5.215300 & 0.0002 \\
LASPI(-2) & -0.088375 & 0.222545 & -0.397113 & 0.6977 \\
LASPI(-3) & -0.317115 & 0.170261 & -1.862525 & 0.0853 \\
LEXC & 0.814870 & 1.113057 & 0.732101 & 0.4771 \\
LEXC(-1) & -3.051610 & 1.497779 & -2.037423 & 0.0625 \\
LEXC(-2) & -2.220106 & 1.595150 & -1.391786 & 0.1873 \\
LEXC(-3) & 4.568965 & 1.355546 & 3.370573 & 0.0050 \\
LMS & -0.488152 & 0.474827 & -1.028063 & 0.3227 \\
LINT & -1.227702 & 0.229897 & -5.340229 & 0.0001 \\
LINT(-1) & 0.781913 & 0.278051 & 2.812118 & 0.0147 \\
LINT(-2) & 0.059657 & 0.272544 & 0.218888 & 0.8301 \\
LINT(-3) & -0.632705 & 0.224619 & -2.816793 & 0.0146 \\
LINF & -0.321099 & 0.106781 & -3.007084 & 0.0101 \\
C & 3.476448 & 1.127498 & 3.083330 & 0.0087 \\
R-squared & 0.985276 & Mean dependent var & 3.309476 \\
Adjusted R-squared & 0.970551 & S.D. dependent var & 0.437828 \\
S.E. of regression & 0.075134 & Akaike info criterion & -2.032932 \\
Sum squared resid & 0.073387 & Schwarz criterion & -1.361017 \\
Log likelihood & 41.44458 & Hannan-Quinn criter. & -1.833137 \\
F-statistic & 66.91447 & Durbin-Watson stat & 1.463781 \\
Prob(F-statistic) & 0.000000 & & & \\
\hline
\end{tabular}

* Note: p-values and any subsequent tests do not account for model selection.

Source: Survey Data, 2021. 
Lingesiya Kengatharan and Jeyan Suganya Dimon Ford

The long-run parameters of the ARDL model are displayed in Table 7. As per the results, when the interest rate and inflation are relevant to stock market development, the estimates indicate a significant causal impact guided from interest rate and inflation to stock market performance at a $5 \%$ level of significance. The exchange rate and money supply have not shown any significant causal impact on stock market performance.

Table 7: ARDL estimates of the long-run relationship

\begin{tabular}{lcccc}
\hline \multicolumn{1}{c}{ Variable } & Coefficient & Std. Error & t-Statistic & Prob. \\
\hline LEXC & 0.272055 & 0.560814 & 0.485107 & 0.6357 \\
LMS & -1.184493 & 1.324453 & -0.894326 & 0.3874 \\
LINT & -2.472195 & 1.114421 & -2.218366 & 0.0450 \\
LINF & -0.779142 & 0.264540 & -2.945274 & 0.0114 \\
\hline EC = LASPI $-\left(0.2721^{*}\right.$ LEXC-1.1845*LMS-2.4722*LINT-0.7791LINF
\end{tabular}

The results of the short-run dynamic relationship associated with the long-run relationship were obtained from the ARDL-ECM equation (Ahmed and Delin, 2019) and the results are presented in Table 8.

Table 8: ARDL short-run estimate and error correction model (ECM)

\begin{tabular}{lcccc}
\hline \multicolumn{1}{c}{ Variable } & Coefficient & Std. Error & t-Statistic & Prob. \\
\hline C & 3.476448 & 0.545010 & 6.378692 & 0.0000 \\
D(LASPI(-1)) & 0.405490 & 0.148650 & 2.727825 & 0.0173 \\
D(LASPI(-2)) & 0.317115 & 0.136155 & 2.329071 & 0.0366 \\
D(LEXCHANGE) & 0.814870 & 0.880680 & 0.925273 & 0.3717 \\
D(LEXCHANGE(-1)) & -2.348859 & 0.838202 & -2.802257 & 0.0150 \\
D(LEXCHANGE(-2)) & -4.568965 & 0.912262 & -5.008390 & 0.0002 \\
D(LINTER) & -1.227702 & 0.160455 & -7.651365 & 0.0000 \\
D(LINTER(-1)) & 0.573048 & 0.192713 & 2.973586 & 0.0108 \\
D(LINTER(-2)) & 0.632705 & 0.166985 & 3.788996 & 0.0023 \\
CointEq(-1)* & -0.412119 & 0.065412 & -6.300343 & 0.0000 \\
R-squared & 0.833345 & Mean dependent var & 0.037238 \\
Adjusted R-squared & 0.745116 & S.D. dependent var & 0.130141 \\
S.E. of regression & 0.065703 & Akaike info criterion & -2.329228 \\
Sum squared resid & 0.073387 & Schwarz criterion & -1.849289 \\
Log likelihood & 41.44458 & Hannan-Quinn criter. & -2.186517 \\
F-statistic & 9.445256 & Durbin-Watson stat & 1.463781 \\
Prob(F-statistic) & 0.000048 & & & \\
\hline
\end{tabular}

* p-value incompatible with t-Bounds distribution.

Source: Survey Data, 2021. 
ECT is statistically significant with negative signs, as shown in table 8. However, the primary goal of ECM is to determine how quickly some deviation from long-run equilibrium can be corrected. In the case of the Sri Lankan stock market equation, the value of ECT (0.4121 ) shows that each year about $41 \%$ of the difference between the real and equilibrium value of stock market result is corrected.

Finally, the cumulative sum (CUSUM) and cumulative sum of squares (CUSUMSQ) are used to examine the stability of long-run coefficients in conjunction with short-run dynamics. The critical bound of $5 \%$ significance is plotted against the CUSUM and CUSUMSQ statistics. Thus, figures 1 and 2 which show the graphical representations of CUSUM and CUSUMQ statistics indicate that the parameters' stability remained within their critical bounds of parameter stability.

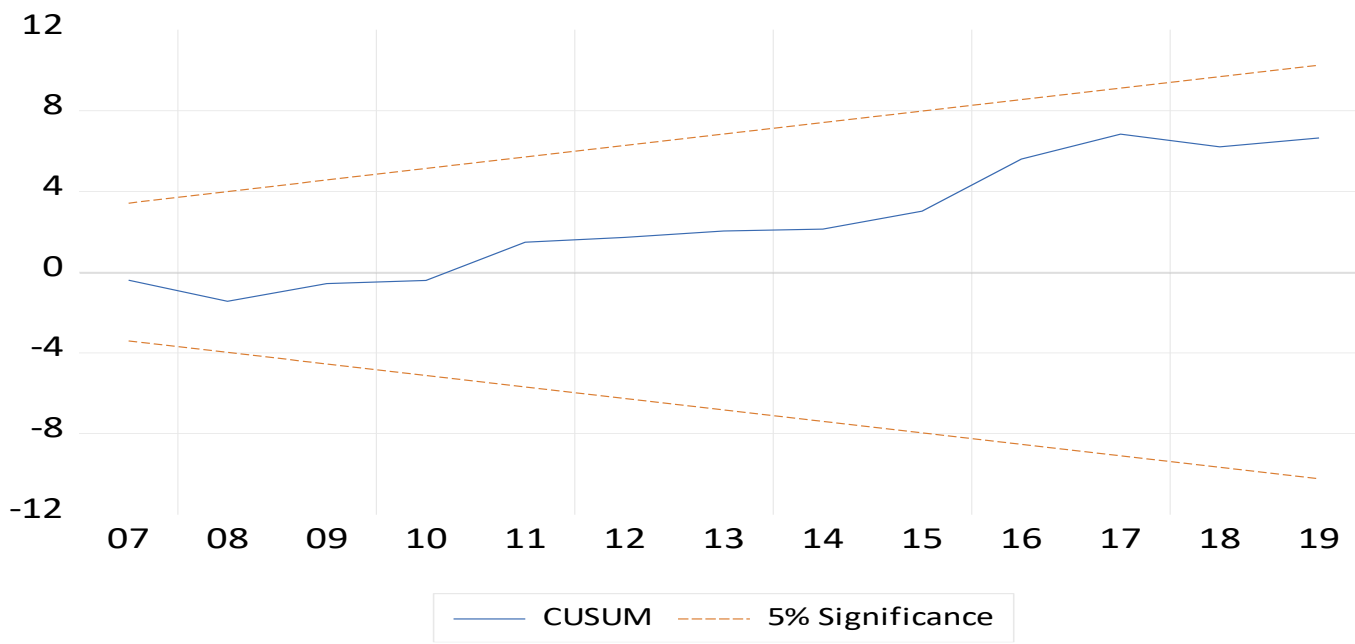

Figure 1: Cumulative Sum (CUSUM) Statistics

The co-integration tests showed that the variables in this study are co-integrated from order (i.e., I(O) and I(1)), indicating that an ARDL technique was suitable for the analysis. The stock market performance in Sri Lanka is co-integrated with relative money supply, according to empirical findings based on the ARDL Model. The Schwarz Bayesian Criterion was used to choose the best $\operatorname{ARDL}(3,3,0,3,0)$ specification. In terms of short-term analysis, the study shows that approximately $41 \%$ of the variation in stock market performance in Sri Lanka is resolved within a year. 


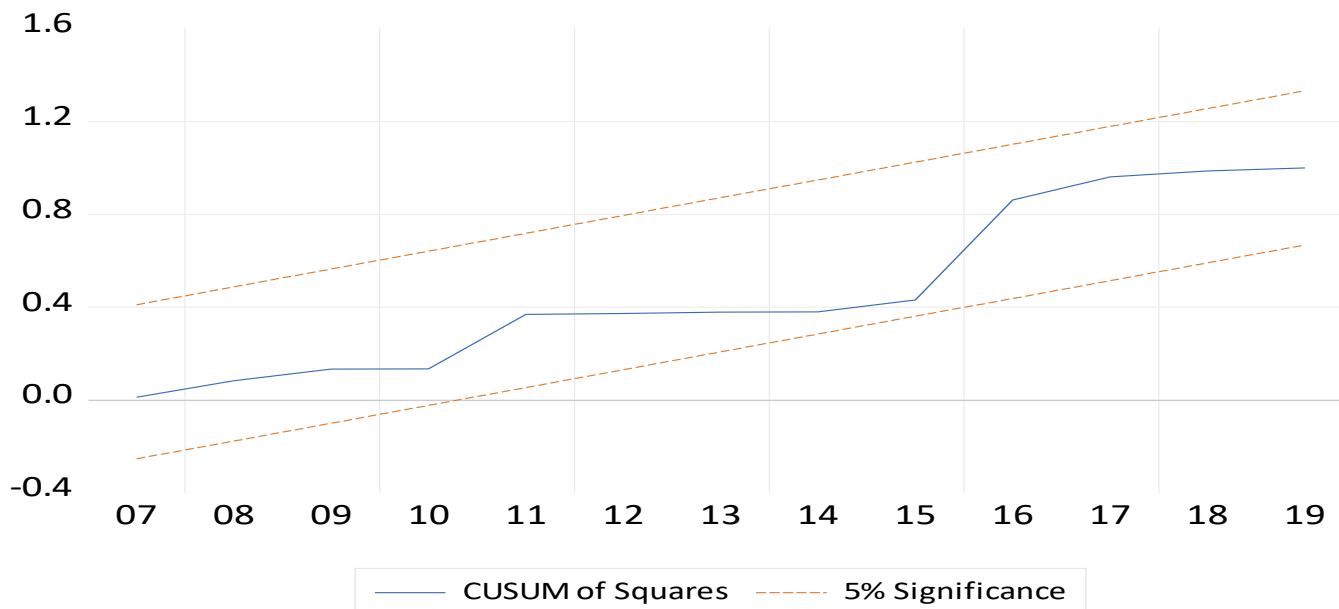

Figure 2- Cumulative Sum of Squares (CUSUMSQ) Statistics

\section{Conclusion}

Using annual data from 1990 to 2019, the current study investigated the effect of macroeconomic variables on stock market performance in Sri Lanka. The main goal of the study was to figure out how macroeconomic factors affect the stock market performance. The output of the stock market was calculated using the All Share Price Index, and macroeconomic variables such as interest rate, inflation, real exchange rate, and money supply were chosen. The data was analyzed using the ARDL bounds test method, after all the variables were converted to log form. The ADF test was used to ensure that the data was stationary. The results of the study revealed that the interest rate and inflation have a negative effect on the stock market performance. Therefore, the monitory policy of the country should be modified by regulatory bodies for maintaining inflation rate and interest rate at a lower level in order to increase the confidence of national and international investors. Furthermore, the exchange rate and money supply have no significant relationship with the stock market performance. However, the interest rate has a negative and substantial effect on the stock market growth.

\section{References}

Ahmed, Y. N. \& Delin, H. (2019). Current situation of Egyptian cotton: econometrics study using ARDL Model. Journal of Agricultural Science, 11(10), 88 - 97

Allahawiah, S., \& Al-Amro, S. (2012). Factors affecting stock market prices in Amman stock exchange: a survey study. European Journal of Business and Management, 4(8), 236245 
Amarasinghe, A. (2015). Dynamic relationship between interest rate and stock price: empirical evidence from Colombo stock exchange. International Journal of Business and Social Science, 6(4), 92-97

Badullahewage, S.U. (2015). The effects of macroeconomic factors on the performance of stock market in Sri Lanka. International Journal of Management Science and Business Administration, 3(6), 33-41

Bhuiyan, M. E., \& Chowdhury, M. (2019). Macroeconomic variables and stock market indices: Asymmetric dynamics in the US and Canada. Quarterly Review of Economics and Finance, 1-37. https://doi.org/10.1016/j.qref.2019.10.005

Bhuiyan, M. E., \& Chowdhury, M. (2020). Macroeconomic variables and stock market indices: Asymmetric dynamics in the US and Canada. The Quarterly Review of Economics and Finance, 77, 2-74.

Chen, S., Wei, W., Huang, P., \& Elkassabgi, A. (2019). Influences of Macroeconomic Variables on Stock Market in China: An Empirical Analysis. Journal of International Finance and Economics, 19(4), 81-93

De Grauwe, P. (2008). Stock prices and monetary policy. CEPS Working Paper, No. 304.

Demir, C. (2019). Macroeconomic determinants of stock market fluctuations: the Case of BIST-100. Economies, 7(8), 1-14.

Emenyi, E., \& Effiong, S. A. (2020). Macroeconomic variables and stock market performance: Covid - vectors or Covid - variables? Journal of Critical Reviews, 7(12), 4685-4693

Engle, R. F., \& Granger, C. W. (1987). Co-integration and error correction: representation, estimation, and testing. Econometrica: Journal of the Econometric Society,55(2), 251276.

Fama, E. F. (1970). Efficient capital markets: A review of theory and empirical work. Journal of Finance, 25(2), 383-417

Fama, E., F. (1965). The behavior of stock market prices. Journal of Business, 38(1), 34105

Granger, C. W., \& Weiss, A. A. (1983). Time series analysis of error-correction models. In Studies in econometrics, time series, and multivariate statistics (pp. 255-278). Academic Press

Hunjra, A. I., Chani, M. I., Ijaz, M. S., Farooq, M., \& Khan, K. (2014). The impact of macroeconomic variables on stock prices in Pakistan. International Journal of Economics and Empirical Research, 2(1), 13-21

Jayasundara, J. M. D. P., Rathnayake, R. M. A. K., \& Fernando,P. J. S. (2019). Impact of macroeconomic variables on stock market performances: evidence from Sri Lanka. Journal of Business Economics, 8(1), 67 - 89

Kalam, K. (2020). The Effects of Macroeconomic variables on stock market returns: evidence from Malaysia's stock market return performance. Journal of World Business, 55, https://www.researchgate.net/publication/344158504 
Lingesiya Kengatharan and Jeyan Suganya Dimon Ford

Khan, J., \& Khan, I. (2018). The impact of macroeconomic variables on stock prices: a case study of Karachi stock exchange. Journal of Economics and Sustainable Development, 9(13), $15-25$

Kumuduni Hemamala, R. K., and Jameel, A. L. M. (2016). Relationship between Inflation and stock market return: special reference to the Colombo stock exchange (CSE). Proceedings of the 5th Annual International Research Conference, 40-48

Laichena, K. E., \& Obwogi, T. N. (2015). Effects of macroeconomic variables on stock returns in the East African community stock exchange market. International Journal of Education and Research, 3(10), 305-320.

Lakmali, A. and Madhusanka, K. J. S. (2015). The effect of macroeconomic variables on stock prices in Sri Lankan Stock Market, International research Symposium Rajarata University of Sri Lanka, pp. 86-93.

Ilah, G. M. W., Islam, A., Alam, M. S., \& Khan, M. K. (2017). Effect of macroeconomic variables on stock market performance of SAARC countries. Asian Economic and Financial Review, 7(8), 770-779.

Menike, L. M. C. S. (2006). The effect of macroeconomic variables on stock prices in emerging Sri Lankan stock market. Sabaragamuwa University Journal, 6(1), 50-67.

Mohapatra, S. M., \& Rath, B. N. (2015). Do macroeconomic factors matter for stock prices in emerging countries? Evidence from panel cointegration and panel causality. International Journal of Sustainable Economy, 7(2), 140-154.

Moore, H. (1962). Stock prices and the business cycle. Journal of Portfolio Management, $1(1), 59-64$.

Morawakage, P. (2013). Relationship between macroeconomic variables and stock market performance of Colombo stock exchange. In International Conference on Business and Information 2013. https://doi.org/10.13140/RG.2.1.1109.6802.

Nanayakkara, M. S. \& Darshi, G.A.N. (2015). The impact of macroeconomic variables on stock market performance in Sri Lanka. International conference on contemporary management, Faculty of Management Studies and Commerce, University of Jaffna.

Nijam, H. M., Ismail, S.M.M. \& Musthafa, A.M.M. (2015). The Impact of macro-economic variables on stock market performance; evidence from Sri Lanka. Journal of Emerging Trends in Economics and Management Sciences, 6(2), 151-157

Nkoro, E. \& Uko, A.K. (2016) Autoregressive Distributed Lag (ARDL) Cointegration Technique: application and interpretation. Journal of Statistical and Econometric Methods, 5(1), 63-91.

Olomu, E. (2015). Impact of macroeconomic variables on UK stock market: A case study of FTSE100 index. Doctoral dissertation, University of East London.

Perera, P. R. M. R. (2015). Macroeconomic variables effect on all share price index in Colombo stock exchange of Sri Lanka. International Journal of Scientific \& Engineering Research, 6(6), 960-961. 
Rathnayaka, R.M.K.T. \& Seneviratna D.M. K. N. (2017). Impact of macroeconomic variables on stock market returns: a case study of Colombo stock exchange, Sri Lanka. Kelaniya Journal of Management, 1-12.

Ross, S. A. (1976). The arbitrage theory of capital asset pricing. Journal of Economic Theory, 13(1), 341-360.

Sahoo, A. P., Patnaik, B. C. M., \& Satpathy, I. (2020). Impact of macroeconomic variables on stock market -a study between India and America. European Journal of Molecular \& Clinical Medicine, 7(11), 4469 - 4486

Shafana, M. (2014). Macroeconomic variables effect on financial sector performance in emerging Sri Lankan stock market. International Journal of Science and Research, 3(10), 227-231.

Thuy, C. T. T. (2018). Analysis of internal and external factors affecting to the stock market price of non-financial joint stock companies listed on the Vietnam's stock market. The 5th IBSM International Conference on Business, Management and Accounting, Hanoi University of Indus try, Vietnam.

Utami, W., Hartoyo, S., \& Maulana, T. (2015). The effect of internal and external factors on stock return: empirical evidence from the Indonesian construction subsector. Asian Journal of Business and Management, 3(5), 370 - 377.

Utomo, S. H., Wulandari, D., Narmaditya, B. S., Handayati, P., \& Ishak, S. (2019). Macroeconomic factors and LQ45 stock price index: Evidence from Indonesia. Investment Management and Financial Innovations, 16(3), 251-259.

Wickremasinghe, G. (2011). The Sri Lankan stock market and the macroeconomy: An empirical investigation. Studies in Economics and Finance, 28(3), 179-195.

\section{Author Biography}

Dr. Lingesiya Kengatharan is a Senior Lecturer in Financial Management attached to the department of Financial Management, Faculty of Management Studies and Commerce, University of Jaffna, Sri Lanka. She has completed her PhD in Accounting and Finance at the Kingston University, UK.

Mrs. Jeyan Suganya Dimon Ford is a Senior Lecturer in Financial Management attached to the department of Financial Management, Faculty of Management Studies \& Commerce, University of Jaffna, Sri Lanka. 